\title{
Economic Selection Indices: The Best Tool for Dairy Cattle Selection ${ }^{1}$
}

\author{
Francisco Peñagaricano ${ }^{2}$
}

\section{Introduction}

Using an economic selection index is the best approach for selecting animals while considering multiple traits (Hazel, Dickerson, and Freeman 1994). This method combines multiple traits into a single value, greatly facilitating the identification of the best animals. Individual traits are weighted based on relevant genetic information, such as heritability and genetic correlations, and their economic importance. These economic weights are based on marginal prices for both inputs and outputs of any dairy production enterprise, such as milk prices, feed prices, and veterinary costs, among others (VanRaden 2004).

\section{Evolution of US Economic Selection Indices}

Economic selection indices are updated periodically in order to include new traits and to reflect price trends (Shook 2006). Table 1 shows the evolution of the USDA Lifetime Net Merit (NM\$) index, which is probably the most popular index in the US dairy industry. The first USDA index, Predicted Difference Dollars (PD\$), included only milk and fat yield. Developed in 1994, the NM\$ combined five traits: milk yield, fat yield, protein yield, productive life, and somatic cell score. Three functional type traits, udder composite, feet and legs composite, and body weight/size composite, were included in NM\$ in 2000 . Subsequent updates included the incorporation of daughter pregnancy rate (2003), calving performance (2006), heifer and cow conception rates (2014), and livability (2017). The NM\$ index was updated in August 2018 with the inclusion of six health traits: clinical mastitis, ketosis, retained placenta, metritis, displaced abomasum, and milk fever. These six common and costly health events are currently evaluated only in animals of the Holstein breed. These six new traits have been added to the indices in the form of a health trait subindex (HTH\$). Overall, the emphasis on yield traits has declined over time as health and fertility traits, commonly grouped as fitness traits, were introduced (Cole and VanRaden 2018).

\section{Economic Selection Indices: 2018 Update}

Currently, there are many selection indices available. For instance, the USDA-ARS Animal Genomics and Improvement Laboratory has four different economic selection indices, including NM\$, Cheese Merit (CM\$), Fluid Merit (FM\$), and Grazing Merit (GM\$). Table 2 describes these four indices and the relative importance of individual traits. These indices simultaneously consider 14 traits or subindices that combine information from 35 individual traits, including production traits (milk, fat, and protein yield), female fertility traits (daughter pregnancy rate, heifer conception rate, and cow conception rate), longevity traits (productive life and livability), functional type traits (udder composite, feet and legs composite, and body weight

1. This document is AN353, one of a series of the Department of Animal Sciences, UF/IFAS Extension. Original publication date March 2019. Visit the EDIS website at https://edis.ifas.ufl.edu for the currently supported version of this publication.

2. Francisco Peñagaricano, assistant professor, Department of Animal Sciences; UF/IFAS Extension, Gainesville, FL 32611.

The Institute of Food and Agricultural Sciences (IFAS) is an Equal Opportunity Institution authorized to provide research, educational information and other services only to individuals and institutions that function with non-discrimination with respect to race, creed, color, religion, age, disability, sex, sexual orientation, marital status, national origin, political opinions or affiliations. For more information on obtaining other UF/IFAS Extension publications, contact your county's UF/IFAS Extension office. 
composite), health traits (somatic cell score and the six new disease resistance traits), and calving ability.

Among the economic selection indices, NM\$ is probably the most appropriate breeding goal for the vast majority of US dairy farmers. Fat and protein yield receive the highest relative weights in NM\$, representing $26.8 \%$ and $16.9 \%$, respectively. Longevity traits, female fertility traits, health traits, and functional type traits receive relative weights of $19.4 \%, 9.7 \%, 6.3 \%$, and $15.4 \%$, respectively. Calving ability (CA\$), a subindex that includes both service-sire and daughter calving ease and stillbirth, receives a relative weight of $4.8 \%$. Overall, current NM\$ has relative weights of $44.4 \%$ for production traits, $40.2 \%$ for fitness traits, and $15.4 \%$ for functional type traits (VanRaden, Cole, and Parker Gaddis 2018).

The FM\$, CM\$, and GM\$ represent alternative selection indices for producers with special milk markets or production systems (Table 2). For dairy producers who are paid mainly for milk volume (i.e., markets in which the incentives for components are insignificant), the FM\$ is probably the most appropriate breeding goal. Fluid merit has relative weights of $18.4 \%$ for milk yield, $27.1 \%$ for fat yield, and $0 \%$ for protein yield (VanRaden, Cole, and Parker Gaddis 2018). For dairy farmers who are paid mainly for milk components, $\mathrm{CM} \$$ is probably the most appropriate economic selection index. Compared to NM\$, CM\$ places more emphasis on protein yield. Milk volume is more penalized, indicating that the selection for more milk solids should be achieved by improving fat and protein percentage rather than improving total milk yield. Pasture-based dairy producers may find the GM\$ index as the most convenient economic selection index. Compared to NM\$, GM\$ places roughly the same emphasis on production and health traits, more emphasis on female fertility traits, and slightly less emphasis on productive life and livability.

\section{Example}

Table 3 shows predicted transmitting abilities (PTAs, or estimates of genetic merit) for milk yield, protein yield, productive life, clinical mastitis, metritis, daughter pregnancy rate, net merit, and fluid merit for three different bulls. It is important to emphasize that selection decisions should be based on selection indices, either NM\$ or FM\$, instead of individual traits. For those producers who use $\mathrm{NM} \$$ as a selection tool, bull A is the best option (i.e., bull A has the highest $\mathrm{NM} \$$ value). On the other hand, for producers who prefer FM\$ because they are paid mainly for milk volume, bull B is the best option. Note that the use of selection indices greatly facilitates the identification of the best animals.

\section{Conclusion}

Economic selection indices should be considered during animal selection when multiple traits are involved. These indices are continually revised in order to incorporate new traits and update economic values. Over time, the focus of selection has shifted from increasing milk yield to improving milk solids and enhancing health and fertility traits. Current selection indices consider more than 30 relevant traits, including production, reproduction, longevity, health, and calving ability traits. New important phenotypes, such as gestation length, age at first calving, and feed efficiency, may be added in the near future.

\section{References}

Cole, J. B. and P. M. VanRaden. 2018. "Symposium review: Possibilities in an age of genomics: The future of selection indices." J. Dairy Sci. 101(4): 3686-3701.

Hazel, L. N., G. E. Dickerson, and A. E. Freeman. 1994. "The selection index-Then, now, and for the future." J. Dairy Sci. 77(10): 3236-3251.

Shook, G. E. 2006. "Major advances in determining appropriate selection goals.” J. Dairy Sci. 89(4): 1349-1361.

VanRaden, P. M. 2004. "Invited review: Selection on net merit to improve lifetime profit." J. Dairy Sci. 87(10): 3125-3131.

VanRaden, P. M., J. B. Cole, and K. L. Parker Gaddis. 2018. "Net merit as a measure of lifetime profit: 2018 revision." AIP Research Report, NM\$7 (5-18). https://aipl.arsusda.gov/ reference/nmcalc-2018.htm\#Updated 
Table 1. History of Lifetime Net Merit (NM\$) Index. Source: Council on Dairy Cattle Breeding (Dec. 2018, https://aipl.arsusda.gov/ reference/nmcalc-2018.htm\#History)

\begin{tabular}{|c|c|c|c|c|c|c|c|c|c|c|c|}
\hline Traits & $\begin{array}{l}\text { PD\$ } \\
\text { (1971) }\end{array}$ & $\begin{array}{l}\text { MFP\$ } \\
\text { (1976) }\end{array}$ & $\begin{array}{c}\text { CY\$ } \\
(1984)\end{array}$ & $\begin{array}{l}\text { NM\$ } \\
\text { (1994) }\end{array}$ & $\begin{array}{l}\text { NM\$ } \\
(2000)\end{array}$ & $\begin{array}{l}\text { NM\$ } \\
(2003)\end{array}$ & $\begin{array}{l}\text { NM\$ } \\
(2006)\end{array}$ & $\begin{array}{l}\text { NM\$ } \\
(2010)\end{array}$ & $\begin{array}{l}\text { NM\$ } \\
(2014)\end{array}$ & $\begin{array}{l}\text { NM\$ } \\
(2017)\end{array}$ & $\begin{array}{l}\text { NM\$ } \\
(2018)\end{array}$ \\
\hline Milk & 52 & 27 & -2 & 6 & 5 & 0 & 0 & 0 & -1 & -1 & -1 \\
\hline Fat & 48 & 46 & 45 & 25 & 21 & 22 & 23 & 19 & 22 & 24 & 27 \\
\hline Protein & --- & 27 & 53 & 43 & 36 & 33 & 23 & 16 & 20 & 18 & 17 \\
\hline Productive Life & --- & --- & --- & 20 & 14 & 11 & 17 & 22 & 19 & 13 & 12 \\
\hline Somatic Cell Score & --- & --- & --- & -6 & -9 & -9 & -9 & -10 & -7 & -7 & -4 \\
\hline $\begin{array}{l}\text { Body Weight } \\
\text { Composite }\end{array}$ & --- & --- & --- & --- & -4 & -3 & -4 & -6 & -5 & -6 & -5 \\
\hline Udder Composite & --- & -- & --- & -- & 7 & 7 & 6 & 7 & 8 & 7 & 7 \\
\hline $\begin{array}{l}\text { Feet \& Legs } \\
\text { Composite }\end{array}$ & --- & -- & --- & -- & 4 & 4 & 3 & 4 & 3 & 3 & 3 \\
\hline $\begin{array}{l}\text { Daughter Pregnancy } \\
\text { Rate }\end{array}$ & --- & -- & --- & --- & --- & 7 & 9 & 11 & 7 & 7 & 7 \\
\hline $\begin{array}{l}\text { CA\$ (calving trait } \\
\text { subindex) }\end{array}$ & --- & --- & --- & --- & --- & --- & 6 & 5 & 5 & 5 & 5 \\
\hline $\begin{array}{l}\text { Heifer Conception } \\
\text { Rate }\end{array}$ & --- & --- & --- & --- & --- & --- & --- & --- & 1 & 1 & 1 \\
\hline Cow Conception Rate & --- & -- & -- & --- & -- & --- & --- & --- & 2 & 2 & 2 \\
\hline Livability & --- & -- & --- & --- & --- & -- & --- & -- & --- & 7 & 7 \\
\hline $\begin{array}{l}\text { HTH\$ (health trait } \\
\text { subindex) }\end{array}$ & --- & --- & --- & --- & --- & --- & --- & --- & --- & --- & 2 \\
\hline
\end{tabular}

Table 2. Economic selection indices, Lifetime Net Merit (NM\$), Cheese Merit (CM\$), Fluid Merit (FM\$), and Grazing Merit (GM\$), and the relative importance (relative weight) of individual traits. Source: Council on Dairy Cattle Breeding (Dec. 2018, https://aipl. arsusda.gov/reference/nmcalc-2018.htm\#Updated)

\begin{tabular}{|c|c|c|c|c|}
\hline Traits & $\begin{array}{c}\text { NMS } \\
(2018)\end{array}$ & $\begin{array}{c}\text { CM\$ } \\
(2018)\end{array}$ & $\begin{array}{c}\text { FM\$ } \\
(2018)\end{array}$ & $\begin{array}{c}\text { GM\$ } \\
\text { (2018) }\end{array}$ \\
\hline Milk & -0.7 & -7.9 & 18.4 & -0.7 \\
\hline Fat & 26.8 & 22.8 & 27.1 & 22.9 \\
\hline Protein & 16.9 & 20.9 & 0 & 14.4 \\
\hline Productive Life & 12.1 & 10.3 & 12.2 & 6.6 \\
\hline Somatic Cell Score & -4.0 & -4.4 & -2.3 & -3.5 \\
\hline Body Weight Composite & -5.3 & -4.5 & -5.3 & -5.8 \\
\hline Udder Composite & 7.4 & 6.3 & 7.5 & 7.4 \\
\hline Feet \& Legs Composite & 2.7 & 2.3 & 2.8 & 2.8 \\
\hline Daughter Pregnancy Rate & 6.7 & 5.7 & 6.8 & 17.8 \\
\hline CA\$ (calving trait subindex) & 4.8 & 4.1 & 4.8 & 4.5 \\
\hline Heifer Conception Rate & 1.4 & 1.2 & 1.4 & 2.4 \\
\hline Cow Conception Rate & 1.6 & 1.4 & 1.7 & 4.3 \\
\hline Livability & 7.3 & 6.2 & 7.4 & 4.9 \\
\hline HTH\$ (health trait subindex) & 2.3 & 1.9 & 2.3 & 2.1 \\
\hline
\end{tabular}

Table 3. Predicted transmitting abilities (PTAs) for milk yield (MY), protein yield (PY), productive life (PL), clinical mastitis (MAST), metritis (MET), daughter pregnancy rate (DPR), net merit (NM\$), and fluid merit (FM\$) for three dairy bulls.

\begin{tabular}{|c|c|c|c|c|c|c|c|c|}
\hline Bulls & MY (lb) & PY (lb) & PL (mo.) & MAST & MET & DPR (\%) & NM\$ & FM\$ \\
\hline A & 328 & 45 & 6.8 & 1.3 & 0.9 & 1.0 & 794 \\
\hline B & 2,734 & 79 & 3.0 & -1.7 & 1.3 & 0.8 & 708 \\
\hline C & 1,919 & 75 & 3.4 & -1.5 & 0.9 & 3.2 & 726 \\
\hline
\end{tabular}

